\title{
READING NOVELS IN THE RENEWED MIDDLE GRADES ENGLISH CLASSROOM:
}

\author{
Some passing thoughts on choosing and using novels from teacher to (future) teacher ${ }^{1}$
}

Jessica Allen Hanssen

Nord University

jessica.a.hanssen@nord.no

Teenagers are interesting. Understatement of the year, right? They're no longer children, but they're not yet adults. There's so much change: physical growth, sexual awareness, emotional upheaval, and brain development. Teenagers are at a crossroads - one we've all been at before. Despite the fact that each of us experienced a different adolescence, with our own share of problems and triumphs, we all made it out alive. We have all, to some extent, been immediately involved with what the kids call "drama," yet we are now (hopefully) more distant from it - the perfect stance for studying said drama in fictional form! Literature written for and about teenagers is especially exciting, because it reflects all these changes. When we read a good young adult (YA) novel, for example, we feel a sense of immediacy that the text is "real," even if it's pure fantasy, and that the stakes and consequences are high. You get involved again.

Go back to your own school days. Obviously, there must have been something that attracted you to studying a second language. Perhaps it was cool to be good at English, since so much entertainment is delivered in English. Perhaps English provided possibilities for adventure. Perhaps you were simply good at languages and wanted to excel. Or perhaps you were one of the ones in the back of the class who didn't much enjoy English at the time, but something about needing to be qualified in several school subjects in order to get a steady

\footnotetext{
${ }^{1}$ The author wishes to acknowledge Jowan Mohammed ( $\mathrm{PhD}$ fellow in history, Nord University) for her gracious input and advice on this essay.
} 


\section{Nordic Journal of Modern Language Methodology}

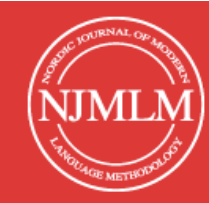

2020, 8 (1), 91-98 (Part B: Not peer reviewed)

government job with summers off spoke to you as you gained a bit more life experience. But at some point, you decided to take your study of English seriously, and here you are, poised and ready to become English teachers. It will become your goal to inspire in your own students to develop whatever it was that sparked your interest in English, as well as to keep learning about new ways that English is important to the evolving world. But you will be competing with a vast array of diversions, and honestly, the available material in the textbooks and the typical novel selection, as you've probably observed in your praxis teaching and in your own school experience, isn't always especially interesting to younger learners, although this is rapidly becoming better. You might not have a lot of choices for material, to be honest.

And then we're competing with phones, computer games, PlayStation, the Internet, social media, movies, TV, and music, most of which takes place in English. Teenagers get bored quickly, and this happens at an increasingly rapid pace thanks to the breakneck transfer of information delivered constantly. Sitting down with a good book just doesn't have the same appeal to students as it might have had for us. In fact, school often has exactly the opposite effect than it intends - for many students, school takes all the fun out of reading in English and turns it into a boring, mechanical function that they do because they have to, not because they want to or because they feel it has anything useful to offer them. Sometimes, in these cases, it's helpful to recast reading in English as something like providing a "cheat code" for real life: if nothing else, reading can help you get ahead, or prevent you from making mistakes, and only complete suckers wouldn't bother trying to get what they could out of things. If and when you do make mistakes, it is in these books and in reading itself that you find comfort in the idea that you are not alone, a quiet fact that YA fiction in particular is great at expressing, and one which we should get used to saying out loud. The same mistakes have been made, and will be made, and you can read about how others have handled these situations, both before and after the act, and from various and diverse perspectives.

Understanding nuance comes from exposure; predictability comes from exposure: so, reading lots of different books, i.e. being presented with many different lifeworlds, provides that invaluable so-called "real world" training adults keep telling teenagers they need. Life really does happen the way it does in books, just not one particular novel, but rather bits and pieces from lots of them. We each "write" our own version of life, but in a way, the stories 
have all been written before. We're looking, through the inclusion of age- and experienceappropriate novels in our English classrooms, to understand that process and to help our students grow from the experiences that are already available as they make their own story.

For students who don't have a problem being motivated to learn English, reading novels provide a "safe" way to experience real-life situations, and the feeling of distance that reading in English, a second language for most, provides can be yet another comfortable buffer. Before beginning to teach a text, we should ask ourselves: why do we read? Why do young people read? Why bother reading in a second language? It is easy enough to answer that people read for pleasure, to obtain knowledge, because they are bored, because they have to for the test (a popular one to be sure), and other reasons. Another important yet often overlooked aspect for young learners is that reading is safe. You can read a book on the most "out there" of subjects, on anything you want to know, really, and the book can't bite you or tell you you're not allowed to read it. Books don't judge you. In addition, it is my feeling that the distance which reading in a second language puts between the reader and the text's message is not a bad thing, because it forces a more focused effort toward interpretation and meaning-seeking. It is easier to immediately recognize that one is not necessarily the implied reader when reading a second-language text, and so making the initial effort towards empathy also becomes easier, or at least more conscious. Reading L2 literature therefore promotes personal growth and aids empathetic development in an important and positive way, which is why "møte med engelskspråklige tekster" is so central in the new, renewed curriculum's core elements. Today's literature for young people exploits this potential for growth. So does reader-response theory, if used correctly: the teacher's role is to be a supportive guide through the literature and to encourage quality responses to what is read.

The most important aspect of generating good responses to a text, however, comes before the book is even purchased. Teachers should strive to choose classroom novels that will generate strong responses. Stories that are about difficult situations or choices are easier to respond to than stories where the choice seems clear. In addition, stories should be relatable, meaning that the actual reader should be able to "put herself into the shoes" of the protagonist, even if there is a considerable social or cultural gap between the actual reader and this main character. Since the purpose of reading novels in English class is to come to terms with that implied reader who would understand everything about the story, it is fine 


\section{Nordic Journal of Modern Language Methodology}

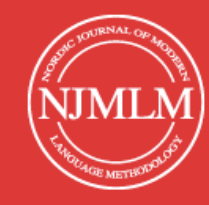

2020, 8 (1), 91-98 (Part B: Not peer reviewed)

that the actual readers do not. In this context, the process of discovery is more important than the knowledge itself. Speaking for myself, I would rather hear a student tell me that they absolutely hate a book (or character) and tell me why, than to hear the dreaded "meh, it was ok" response. I can work with hate, but apathy is much harder to overcome.

In either case, providing sensitive texts, as well as using appropriate methods to bring them to life, can motivate learners at all levels, and also provide them with a sense of accomplishment and purpose as they hit that developmental crossroads themselves. We therefore have an obligation as teachers to choose texts that will captivate our students emotionally and cognitively while still promoting the development of second language skills. This probably won't happen by dragging them kicking and screaming through a scene-byscene breakdown of Of Mice and Men or The Great Gatsby (young Leonardo DiCaprio and Jay-Z film soundtrack aside). Since these texts don't necessarily match a teenager's developmental interests and goals, they do not develop a personal relationship to these texts, and thus assigning texts like these doesn't create an especially "exemplary environment" for learning. (For those who would like to know more about my ideas on how such an environment can be created, with reference to Klafki and thoughtful engagement with instructional technology, I would refer you to my publication on the theme: Hanssen, 2018). We all know how utterly egocentric teenagers are - if they can't put themselves in the scene, they're outta there! Thing are getting better, but the popular reading lists for middle school English still lean pretty heavily on writers who address adult issues from a clearly adult perspective, or, worse, stories that are so obviously written to be somehow educational? Just because students can make their way from point $A$ to point $B$ to point $C$ in terms of the grammar or vocabulary doesn't mean that the story speaks to them. It's equally vital to recognize the importance of teaching books that meet the students where they are at developmentally. Being able to understand every word on the page doesn't matter much if the story stinks and is boring - and this is the inevitable reaction to anything that is over a teenager's head, even the classics. Students frequently lack the vocabulary, patience, and experience to express the developmental gap between themselves and the literature. My idea is to eliminate that gap as much as possible and get to the good part, which is building responses and meaning through interaction. 
The tendency of some teachers of young adults to skip the class novel experience because it is too hard, too boring, or too difficult to find a novel that will suit everyone outside of the tried and true, can create a bad cycle: students think of long-form literature as something they cannot understand; therefore, they think they are not "good at English" or not intelligent individuals. This isn't to say that the classics don't have their place - far from that. It is my opinion, though, that for non-motivated students, reading YA lit provides a good bridge to more traditional texts, and also improvement in English skills, because it builds the “tolerance" for reading. There's time for the classics later, but if the habit of reading isn't established early on, then it becomes harder and harder for them to scale that wall as they get older. This goes for reading in Norwegian or other languages as well. YA literature is consciously written to help us break these cycles before they become fixed, while the learner's brain is still plastic.

Some English teachers, including some of yours, have introduced the idea of "selfselected" novels as a way of not having to make an informed choice while still holding on to the basic idea that reading novels in school is a good thing. I'm aware of the theories about why this works, and it's even in the renewed national curriculum ("lese, diskutere og videreformidle innhold fra ulike typer tekster, inkludert selvvalgte tekster"), so we might be tied to the mast on this one. In the best cases, self-selection can allow learners who are already motivated for reading to explore their interests, which may well include the trials of farm hands in 1930s California. Those who are keen, or hipsters-in-training, will find their way to the classics. I also see a lot of wasted potential here, though: for the "good" readers, they lose an opportunity to expand their repertoire beyond books and subjects they already like and will continue to like anyway, and for the "not-so-good" readers, it allows them to take the path of least resistance, and reinforces the idea that there isn't much to be gained from reading fiction in English. For both, it denies the English teacher what I see as one of our essential roles: that of taste-maker. Why not capitalize on the fact that English teachers are by definition the most sophisticated, worldly, and altogether coolest teachers in the game? (Apologies to any cool maths, science, history, Norwegian, or other subject teachers, but we all know it's true. This is reinforced consistently in pop culture, if nothing else.) We have an important chance to illustrate our values through our choice of reading material. Why say that "diversity" or "justice" are important, or that "Black Lives Matter," when you can create a 


\section{Nordic Journal of Modern Language Methodology}

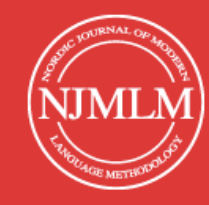

2020, 8 (1), 91-98 (Part B: Not peer reviewed)

reading experience featuring new narrators, situations, and themes that puts your money where your mouth is? Why say that "community" is important when everyone is allowed to do their own thing? That said, it's a complex decision to use a classroom novel, and it requires that the teacher have considerable reading experience, and is prepared to use the same novel in several different ways, to accommodate special learning needs and different learning styles.

(I should probably include a trigger warning here, because I am about to say something controversial...) It also, I'm afraid to say, occasionally means dipping into your own pocket to ensure that, if you decide to teach a classroom novel, the class sets you want are available for your use. American teachers have been doing this for decades, and while this kind of thinking might be anathema to the ideas of the welfare state, in which our professional needs should be met without personal cost, in practice, not all districts and schools are this fortunate. As starting teachers, you might be in a teaching situation that does not allow you to have much direct library input, and you have so many other systems to navigate, so why not make this one easy for yourself? For all its many faults and shortcomings, one positive outcome of Our Amazon Life ${ }^{\mathrm{TM}}$ is that used books can be bought for "pennies on the dollar": that plus some contact paper can make a world of difference to what kind of interpretative community you can create from the start of your teaching careers. If you are in a situation where you can introduce a classroom novel as part of your practice teaching experience, you can double down on your investment, as navigating the classroom novel can form an important and original basis for your project or even thesis work, and carry with you into your own classroom when you're ready.

If we have as our understanding that the purpose of reading, both in and out of school, is to learn about the world around us, and prepare us for its richness, then it is essential to be able to ground our responses to the world with knowledge about our place in it. Each reader of a novel has a unique set of experiences that influence the way she understands and interprets literature, and with that comes a responsibility to share that experience with other readers, so that they can grow in self-awareness and also in empathy.

Comfort engaging various theoretical approaches, no matter how simplified, can help learners express themselves more fully and fluently. Reader-response theory, as a way into literature, places the reader at the forefront of a discussion of what she reads as a vital 


\section{Nordic Journal of Modern Language Methodology}

member of an interpretative community. Narratology, gender theory, or psychoanalytical theory, as outlooks on how texts function to evoke meaning, give us the scientific vocabulary to say not just what a text makes us feel, but why or how it makes us feel that way. Teachers of literature, whether in a first or second language, would therefore do well to incorporate texts and approaches that encourage quality responses to the literature and which allow learners to empathize with people different than themselves. Young adult novels, even those written as graphic novels, can accomplish these goals as readily as any other genre or format, and perhaps even more so. What little literature time we get in an English classroom should be a time of growth and development, in language as well as in social and personal awareness. Choosing a critical approach to novels, with texts and activities that encourage the growth of an interpretative community made of individual readers working towards common yet individual understandings of the world, therefore seems like a worthwhile and practical method for getting the most out of classroom time with your students.

As a kind of conclusion, I would like to welcome all of you to the supremely rewarding profession of teaching English language literature, and it is my hope that you will continue to seek out the literature and ways of working with it (including those found here in this journal) that can enhance your - and your students' - experience. We are rather privileged to be teaching English in a country where censorship and bans on controversial ideas in literature are not a major issue, in a time when conversations about tolerance, respect, and justice are increasingly important, and with an understanding that individual teachers have a great deal of autonomy within the context and flexibility of the renewed national curriculum to make informed literature choices that can actually make a life-altering difference for their students. I would implore you to make the most of this situation, and if you get the chance to teach even one novel a year, to make it a powerful one.

\section{References and further reading:}

Hanssen, J. A. (2018). Teaching English for real life: Reader-response theory and the Bildung tradition. In: Kategorial danning og bruk av IKT i undervisning. Ed. Kåre Fuglseth. Idunn, 2018. 154-167. https://www.idunn.no/kategorial-danning-og-bruk-av-ikt-iundervisning/9-teaching-english-for-real-life 


\section{Nordic Journal of Modern Language Methodology}

Hanssen, J.A. and Jensvoll, M. (2020). Linking Criticality and Creativity: Engagement with Literary Theory in Middle Grades English Education. In: Handbook of Research on Cultivating Literacy in Multilingual and Diverse Classrooms. Eds. G. Neokleous, A. Krulatz, and R. Farrelly. IGI Global, 2020. 261-287.

Norwegian Directorate of Education and Training (2019). Læreplan i Engelsk [Curriculum for English]. Retrieved from: https://data.udir.no/k106/v201906/laereplaner$\underline{\text { lk20/ENG01-04.pdf }}$ 